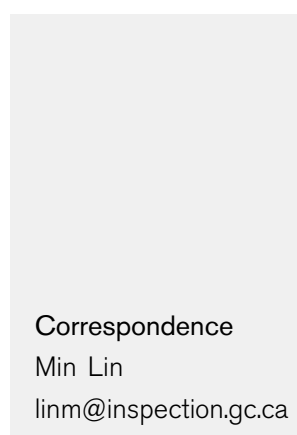

Received 23 August 2005

Accepted 8 November 2005

\section{Monoclonal antibodies binding to the cell surface of Listeria monocytogenes serotype $4 \mathrm{~b}$}

\author{
Min Lin, Dobrila Todoric, Maria Mallory, B. Steven Luo, Erin Trottier \\ and Hanhong Dan
}

Animal Diseases Research Institute, Ottawa, Ontario, Canada K2H 8P9

\section{INTRODUCTION}

Listeria monocytogenes is a Gram-positive, rod-shaped, facultatively anaerobic, intracellular bacterium that causes infection (listeriosis) in man and animals. Individuals most susceptible to the pathogen include neonates, pregnant women, the elderly, immunocompromised persons and those with impaired cell-mediated immunity such as human immunodeficiency virus-infected patients. Common clinical syndromes of listeriosis include septicaemia, meningitis, encephalitis, febrile gastroenteritis, abortion and stillbirths. The organism is ubiquitous in nature and is found in water, soil and vegetation. It grows and survives in extreme conditions, such as a wide range of temperatures from $-1 \cdot 5$ to $50{ }^{\circ} \mathrm{C}$, a pH range of $4 \cdot 3-9 \cdot 6$ (Donnelly, 2001) and high salt concentrations, and can tolerate freezing and drying, making it an ideal candidate for transmission through food and rendering it a difficult organism to eliminate from food

Abbreviations: $\mathrm{H}+\mathrm{L}$, heavy and light; IC, insoluble cellular; WC, whole cell. chains. Transmission from mother to fetus is the only documented form of person-to-person transmission (Lorber, 1997). Food-borne listeriosis has become a great concern to public health and food industries due to a number of outbreaks and sporadic cases caused by foods contaminated with L. monocytogenes (Lorber, 1997; Schlech, 2000; Donnelly, 2001). Although listeriosis is a rare human illness, it is a leading cause of mortality from a food-borne pathogen (Mead et al., 1999). This fact emphasizes the need to develop a rapid detection system for $L$. monocytogenes.

In comparison with culture methods followed by biochemical tests, nucleic acid-based and antibody-based methods have been demonstrated to be very promising for rapid detection of L. monocytogenes in food and clinical samples (Ralovich, 1993; Norton, 2002). Monoclonal antibodies (mAbs) with high specificity and affinity for L. monocytogenes are essential for the development of an immunoassay to detect this pathogen. The production of mAbs to Listeria spp. has been described in a number of studies (Ziegler \& Orlin, 1984; Farber \& Speirs, 1987; McLauchlin et al., 1988; 
Bhunia et al., 1991; Bhunia \& Johnson, 1992; Torensma et al., 1993; Kathariou et al., 1994; Loiseau et al., 1995). However, none of the mAbs reported to date are specific for L. monocytogenes strains with the exception of mAb EM-7G1 described by Bhunia \& Johnson (1992). Almost all human infections are attributed to serotypes $4 \mathrm{~b}, 1 / 2 \mathrm{a}$ and $1 / 2 \mathrm{~b}$ (Lorber, 1997; Donnelly, 2001), with serotype 4b strains accounting for approximately $40 \%$ of cases (Rocourt \& Bille, 1997). Thus, immunoassays specific for serotype 4 b strains are very useful for epidemiological investigations. Kathariou et al. (1994) reported two mAbs, c74.33 and c74.180, that showed a high degree of specificity for serotype $4 \mathrm{~b}$ strains, but also recognized serotypes $4 \mathrm{~d}$ and $4 \mathrm{e}$. It would be of great interest and is also of necessity to develop mAbs for the purpose of developing a laboratory diagnostic test specific for serotype $4 \mathrm{~b}$ strains.

We are interested in immunogenic surface proteins of $L$. monocytogenes, which are less characterized and understood. Study of such proteins may provide new insights into the mechanisms of Listeria pathogenesis, virulence and immunity. As such, our laboratory has initiated a series of studies aimed at the identification and characterization of the immunogenic surface proteins of L. monocytogenes ( $\mathrm{Yu}$, 2004), including the production and characterization of mAbs to L. monocytogenes as described in this paper. The reactivity of these mAbs with several important food-borne pathogens (Escherichia coli O157: H7, Salmonella enterica, Campylobacter jejuni), several Listeria species and L. monocytogenes serotypes was examined using ELISA, Western blots, immunofluorescence microscopy and immunogold electron microscopy to identify mAbs binding specifically to the cell surface of L. monocytogenes serotype $4 \mathrm{~b}$. These mAbs may be useful for probing the surface antigenic composition of L. monocytogenes and may also have potential use in the detection of L. monocytogenes for epidemiological investigations, food safety surveillance, diagnosis, serotyping and pathological studies.

\section{METHODS}

Chemicals and reagents. Horseradish peroxidase (HRP)conjugated goat anti-mouse IgG $(\mathrm{H}+\mathrm{L}$ chain) and $12 \mathrm{~nm}$ colloidal gold-conjugated goat anti-mouse IgG $(\mathrm{H}+\mathrm{L}$ chain) were purchased from Jackson ImmunoResearch Laboratories. Fluorescein isothiocyanate (FITC)-labelled goat anti-mouse $\operatorname{IgG}(\mathrm{H}+\mathrm{L}$ chain) was bought from Zymed Laboratories. Protein standards (pre-stained), nitrocellulose membranes, the protein assay kit and the HRP-conjugate substrate kit were obtained from Bio-Rad. DNase I and RNase A were purchased from Roche Diagnostics; a protease inhibitor cocktail, 2,2'-azino-bis(-ethylbenzthiazoline-6-sulfonic acid) (ABTS) and Freund's adjuvant were from Sigma-Aldrich. The mAb M2165 (tissue-culture fluid) directed against the $\mathrm{E}^{\text {rns }}$ protein of Classical swine fever virus has been described previously (Lin et al., 2005) and was used as a negative control for ELISA, Western blots, immunofluorescent labelling and immunogold labelling studies. All other chemicals were of commercially available analytical grade.

Bacterial culture. L. monocytogenes LI0521 (serotype 4b) and Listeria innocua were maintained on trypticase soy blood agar plates at $4{ }^{\circ} \mathrm{C}$. A single Listeria colony was inoculated into Luria-Bertani
(LB) broth containing $50 \mathrm{mM}$ MOPS ( $\mathrm{pH} \mathrm{7 \cdot 5)}$ and cultured at $37^{\circ} \mathrm{C}$ for $16-18 \mathrm{~h}$. The Listeria cell number was determined from the absorbance reading, with an $\mathrm{OD}_{620}$ value of 0.61 being equivalent to $1 \times 10^{9}$ bacteria $\mathrm{ml}^{-1}$ (Schlech, 1993), and confirmed by plating serial dilutions of cells onto LB agar plates. E. coli O157: H7 ATCC 43889 and S. enterica SA03-1907 serovar Typhimurium DT104 (S. Typhimurium), maintained on LB agar plates at $4{ }^{\circ} \mathrm{C}$, were used to inoculate LB broth and cultured at $37^{\circ} \mathrm{C}$ for $16-18 \mathrm{~h}$. The cell density of $E$. coli was calculated based on an $\mathrm{OD}_{600}$ value of 1 being equivalent to $1 \times 10^{9}$ cells ml $^{-1}$ (Ausubel et al., 2005). The number of $S$. Typhimurium was estimated by plating serial dilutions of cells onto LB agar plates. A pure culture of C. jejuni NCTC 11168 , from the bacteriology stock culture collection at the Animal Diseases Research Institute was streaked onto 25 cysteine heart blood agar plates to produce well-isolated colonies. The plates were placed into anaerobic jars and incubated microaerophilically at $35^{\circ} \mathrm{C}$ for 3 days. The microaerophilic conditions were generated by evacuating and filling the air content in the jars three times with a gas mixture of $3 \cdot 5 \% \mathrm{O}_{2}, 10 \% \mathrm{CO}_{2}$ and $86 \cdot 5 \% \mathrm{~N}_{2}$.

Preparation of $\boldsymbol{L}$. monocytogenes immunogens and immunization of mice. For preparation of insoluble antigens of L. monocytogenes, cells were harvested from $200 \mathrm{ml}$ overnight culture $\left(\sim 1 \cdot 8 \times 10^{11}\right.$ cells) by centrifugation at $10000 \mathrm{~g}$ for $10 \mathrm{~min}$ at $4{ }^{\circ} \mathrm{C}$, washed three times with PBS and killed by resuspending in $30 \mathrm{ml}$ $0.3 \%$ formalin solution in PBS for $24 \mathrm{~h}$ at room temperature. Cell pellets were washed with PBS, resuspended in $30 \mathrm{ml}$ PBS containing $45 \mu \mathrm{g}$ protease inhibitor cocktail $\mathrm{ml}^{-1}$ (Sigma) and disrupted by passing through a French Press at 1500 p.s.i. $(10350 \mathrm{kPa})$. The homogenate was treated with DNase I $\left(100 \mu \mathrm{g} \mathrm{ml}^{-1}\right)$ and RNase A $\left(100 \mu \mathrm{g} \mathrm{ml}^{-1}\right)$ at $37^{\circ} \mathrm{C}$ for $30 \mathrm{~min}$ and then spun at $100000 \mathrm{~g}$ for $80 \mathrm{~min}$ at $4{ }^{\circ} \mathrm{C}$. The pellets, designated insoluble antigens, were resuspended in $3 \mathrm{ml} \mathrm{PBS}$ and stored at $-20^{\circ} \mathrm{C}$ until use. For preparation of formalin-killed L. monocytogenes, cells were harvested from $40 \mathrm{ml}$ overnight culture, washed as above and adjusted to a

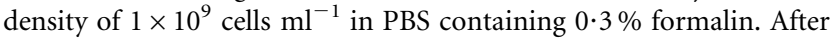
incubation at room temperature for $24 \mathrm{~h}$, cells were centrifuged at $10000 \mathrm{~g}$ for $10 \mathrm{~min}$ at $4{ }^{\circ} \mathrm{C}$, washed with PBS and resuspended in an equal volume of PBS. Formalin-killed L. monocytogenes cells were stored at $-20{ }^{\circ} \mathrm{C}$ until use.

Each of three ND4 mice, after their pre-immune sera were collected, was immunized subcutaneously with insoluble antigens derived from $6 \times 10^{9}$ cells in $0 \cdot 1 \mathrm{ml}$ PBS emulsified with an equal volume of complete Freund's adjuvant at day 0 . Booster injections with the same amount of immunogens emulsified with incomplete Freund's adjuvant were given at days 14 and 28. After resting for at least 4 weeks, mice were given a final intravenous injection with the insoluble antigens (in $100 \mu \mathrm{l}$ PBS) derived from $6 \times 10^{9}$ cells and sacrificed within 1 week for fusions. For immunization with formalin-killed cells, each of three ND4 mice was injected intraperitoneally with $2.5 \times 10^{8}$ cells in $0.25 \mathrm{ml}$ PBS at days 0,14 and 28. Mice were given a final intravenous booster injection with $2 \cdot 5 \times 10^{7}$ cells in $0 \cdot 15 \mathrm{ml}$ PBS after resting for at least 4 weeks and sacrificed for fusion as above.

Preparation of bacterial ELISA antigens. L. monocytogenes $\left(9 \times 10^{11}\right.$ cells) from 1 litre overnight culture were killed with formalin, washed and disrupted in $15 \mathrm{ml}$ PBS containing a protease inhibitor cocktail $\left(45 \mu \mathrm{g} \mathrm{ml}^{-1}\right)$ using a French Press. The homogenate, designated whole-cell (WC) antigens, was treated with DNase I and RNase A as above. The insoluble cellular (IC) antigens of L. monocytogenes were also prepared from 1 litre overnight culture $\left(9 \times 10^{11}\right.$ cells) and resuspended in $5 \mathrm{ml}$ PBS. WC antigens from other bacteria were prepared essentially as above: L. innocua WC antigens from $500 \mathrm{ml}$ overnight culture $\left(3 \cdot 3 \times 10^{11}\right.$ cells $)$ were resuspended in $10 \mathrm{ml}$ PBS; E. coli O157: H7 WC antigens from $200 \mathrm{ml}$ overnight culture $\left(2 \cdot 4 \times 10^{11}\right.$ cells) were resuspended in $15 \mathrm{ml} \mathrm{PBS}$; . 
Typhimurium WC antigens from $50 \mathrm{ml}$ overnight culture $(3 \cdot 3 \times$ $10^{11}$ cells) were resuspended in $10 \mathrm{ml}$ PBS; and C. jejuni WC antigens from a $200 \mathrm{ml}$ cell suspension $\left(\mathrm{OD}_{600}=1 \cdot 35\right)$ were harvested by washing $25100 \mathrm{~mm}$ plates with PBS and resuspended in $10 \mathrm{ml}$ PBS. All antigen preparations were stored at $-20^{\circ} \mathrm{C}$ until use.

Production of murine mAbs. Spleen cells, harvested from two ND4 mice receiving formalin-killed bacteria and from one ND4 mouse immunized with the insoluble antigens, were fused with $\mathrm{Sp} 2 /$ 0-Ag14 myeloma cells (Shulman et al., 1978), essentially according to established procedures (Zola, 1987). Culture supernatants from hybridoma cells were screened for Listeria-reactive mAbs by ELISA using $\mathrm{WC}$ antigens or the IC antigens derived from L. monocytogenes serotype 4b. A Nunc microwell plate (VWR) was coated with the antigens at a pre-determined dilution $(1: 400)$ in $60 \mathrm{mM}$ carbonate

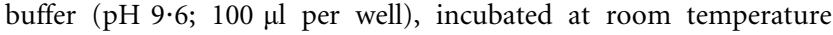
overnight and then frozen at $-20^{\circ} \mathrm{C}$ until use. After the plates had been thawed and washed with PBS-T $(0.05 \%$ Tween 20 in PBS, $\mathrm{pH} 7 \cdot 2)$, hybridoma culture supernatants $(100 \mu \mathrm{l}$ per well) were added to react with the solid-phase antigens for $1 \mathrm{~h}$ at room temperature. Mouse anti-Listeria immune sera at pre-determined dilutions and $10 \%(\mathrm{v} / \mathrm{v})$ fetal calf serum in the hybridoma growth medium were included as controls. Plates were washed with PBS-T, followed by incubation with HRP-conjugated goat anti-mouse IgG ( $1: 4000$ dilution in PBS-T, $100 \mu \mathrm{l}$ per well) for $1 \mathrm{~h}$ at room temperature. After a final wash with PBS-T, substrate solution containing $1 \mathrm{mM}$ ABTS and $0.015 \% \mathrm{H}_{2} \mathrm{O}_{2}$ in $50 \mathrm{mM}$ sodium citrate buffer $(\mathrm{pH} 4 \cdot 5)$ was added to each well $(100 \mu \mathrm{l}$ per well). Following incubation with moderate shaking for $10 \mathrm{~min}$ at room temperature, $A_{414}$ was determined on a Labsystems Multiskan Bichromatic plate photometer. Hybridomas cell lines secreting reactive mAbs were identified by using an empirical $A_{414}$ cut-off of 0.3 under the conditions used.

Isotyping of murine immunoglobulins. The subclasses of immunoglobulins (Igs) secreted by the hybridoma cell lines were determined according to the standard operation procedures MCPR021.02 and MC-PR022.03 (Canadian Food Inspection Agency, Ottawa Laboratory Fallowfield, Ottawa, Ontario, Canada). Briefly, $20 \mu$ hybridoma tissue culture fluid, pre-diluted $1: 2$ with Trisbuffered saline $(0 \cdot 01 \mathrm{M}$ Tris/ $\mathrm{HCl} \mathrm{pH} 8 \cdot 0,0 \cdot 15 \mathrm{M} \mathrm{NaCl})$ containing $0.05 \%(\mathrm{v} / \mathrm{v})$ Tween and $0.02 \%(\mathrm{w} / \mathrm{v}) \mathrm{NaN}_{3}$, was incubated for $15 \mathrm{~min}$ at room temperature with $0.7-0.9 \mu \mathrm{m}$ polystyrene beads (IDEXX Laboratories) that had been pre-coated with goat anti-mouse $\operatorname{Ig}(\operatorname{IgM}+\operatorname{IgG}+\operatorname{IgA}, \mathrm{H}+\mathrm{L}$ chain-specific) (Southern Biotechnology) in the wells of Fluoricon assay plates (IDEXX Laboratories). After washing, bound murine Ig was detected with FITC-conjugated goat anti-mouse $\mathrm{H}+\mathrm{L}$ chain-specific antibodies (Southern Biotechnology) using a Baxter fluorescence concentration analyser (IDEXX Laboratories). Negative and positive tissue-culture fluid controls were performed in parallel with the tested hybridoma tissue fluids.

Analysis of cross-reactivity of anti-L. monocytogenes mAbs with other micro-organisms. L. monocytogenes-reactive mAbs were assessed for cross-reactivity with L. innocua, E. coli O157:H7, $S$. Typhimurium and C. jejuni by indirect ELISA essentially as described above using the respective WC antigens.

Electrophoresis and Western blotting. SDS-PAGE was performed by the method described by Laemmli (1970), using a $4 \%$ stacking gel and a $12 \%$ resolving gel in a minigel apparatus (BioRad). The protein samples for SDS-PAGE were prepared as follows. L. monocytogenes serotype $4 \mathrm{~b}$ (overnight culture) was subcultured at a $1: 100$ dilution in $500 \mathrm{ml}$ growth broth at $37^{\circ} \mathrm{C}$ for $4 \mathrm{~h}$. Bacterial cells, equivalent to a $50 \mathrm{ml}$ culture with an $\mathrm{OD}_{620}$ of $0 \cdot 5$, were harvested by centrifugation $(8000 \mathrm{~g}, 20 \mathrm{~min})$ and suspended in $1 \mathrm{ml}$ $0 \cdot 5 \mathrm{M}$ Tris $/ \mathrm{HCl}(\mathrm{pH} 6 \cdot 8)$ containing $10 \%$ SDS and $1 \mathrm{mM}$ PMSF.
The cell suspension was sonicated ten times for $30 \mathrm{~s}$ each with 1 min intervals. Lysed cells were pre-incubated with an equal volume of $2 \times \mathrm{SDS} / \beta$-mercaptoethanol sample buffer at $100^{\circ} \mathrm{C}$ for $10 \mathrm{~min}$ and then loaded $(20 \mu \mathrm{l})$ into each well of the gels. Following electrophoresis at $200 \mathrm{~V}$, proteins were either stained with Coomassie blue or electroblotted onto nitrocellulose membrane using a Bio-Rad Trans-Blot SD semi-dry transfer cell according to the manufacturer's manual. The membrane, which had been stained with $0 \cdot 1 \%(\mathrm{w} / \mathrm{v})$ Ponceau $\mathrm{S}$ in $5 \%(\mathrm{v} / \mathrm{v})$ acetic acid to ensure the presence of proteins, was blocked with $3 \%$ skimmed milk in PBS containing $0.05 \%$ Tween 20 and $0.2 \%$ Triton X-100 (PBS-TT) for at least $1 \mathrm{~h}$ and incubated at room temperature with specific mAbs at a predetermined dilution in PBS-TT containing $3 \%$ BSA. Bound antibodies were detected using HRP-conjugated goat anti-mouse IgG (Jackson ImmunoResearch Laboratories) and a 4-chloro-1-naphthol/ $\mathrm{H}_{2} \mathrm{O}_{2}$ substrate kit (Bio-Rad) according to the manufacturer's instructions.

Immunofluorescent staining. Binding of mAbs to the cell surface of L. monocytogenes was detected by immunofluorescent staining. Bacterial cells $\left(2 \times 10^{8}\right)$ from an overnight culture were spun at 13000 r.p.m. in a microfuge for 2 min to remove the culture supernatant. Cell pellets were resuspended in $500 \mu \mathrm{l}$ PBS containing $5 \%$ BSA, gently rocked for $1 \mathrm{~h}$ and then incubated for $1 \mathrm{~h}$ with $500 \mu \mathrm{l}$ anti-Listeria $\mathrm{mAb}$ (tissue-culture fluid) at a dilution of 1:50 in PBS containing $5 \%$ BSA. After washing twice with $500 \mu \mathrm{l} \mathrm{PBS}$, pellets were incubated for $1 \mathrm{~h}$ with $250 \mu \mathrm{l}$ FITC-conjugated goat antimouse $\operatorname{IgG}(\mathrm{H}+\mathrm{L}$ chain) at a $1: 100$ dilution in PBS containing $5 \%$ BSA. Cell pellets were washed three times with PBS and resuspended in $50 \mu \mathrm{lBS}$. One drop of the cell suspension was deposited onto a microscope slide, covered with a coverslip and sealed with Cytoseal 60 (VWR). Cells were viewed under an epifluorescence microscope.

Immunogold labelling for electron microscopy. L. monocytogenes serotype $4 \mathrm{~b}\left(3 \times 10^{8}\right.$ cells $)$ from overnight culture were centrifuged at 13000 r.p.m. for $2 \mathrm{~min}$, washed twice with PBS and blocked with $500 \mu \mathrm{l}$ PBS containing $3 \%$ BSA for $30 \mathrm{~min}$ at room temperature with a slow rotation. After washing with PBS, cells were incubated with a specific $\mathrm{mAb}$ at a $1: 25$ dilution in $0.5 \mathrm{ml}$ PBS containing $3 \%$ BSA at room temperature for $1 \mathrm{~h}$. Cells were then washed three times with PBS and incubated with $12 \mathrm{~nm}$ colloidal gold-conjugated goat anti-mouse IgG $(\mathrm{H}+\mathrm{L}$ chain) at a $1: 30$ dilution in $0.3 \mathrm{ml}$ PBS containing $3 \%$ BSA for $30 \mathrm{~min}$ as above. After three final washings with $\mathrm{PBS}$ followed by $\mathrm{H}_{2} \mathrm{O}$, cells were resuspended in $50 \mu \mathrm{l} \mathrm{H}_{2} \mathrm{O}$, adsorbed onto a carbon-coated nickel grid and stained with $0.5 \%$ uranyl acetate $(0.22 \mu \mathrm{m}$ filtered) for $5 \mathrm{~s}$. Bacteria labelled with gold particles were viewed with a transmission electron microscope.

\section{RESULTS}

\section{Production of mAbs to $L$. monocytogenes}

The hybridomas resulting from three fusions, two with mice immunized with $L$. monocytogenes cells and one with a mouse inoculated with the IC antigen preparation, were screened for reactivity of secreted antibodies with $L$. monocytogenes by ELISA (Fig. 1a, b). A total of $35 \mathrm{mAbs}$ (Table 1) was selected for further characterization on the basis of the mAbs ability to recognize both WC and IC antigens of L. monocytogenes. Of these $35 \mathrm{mAbs}, 13$ belonged to Ig subclass G1 (IgG1), 15 were IgG2a and 7 were IgM. 

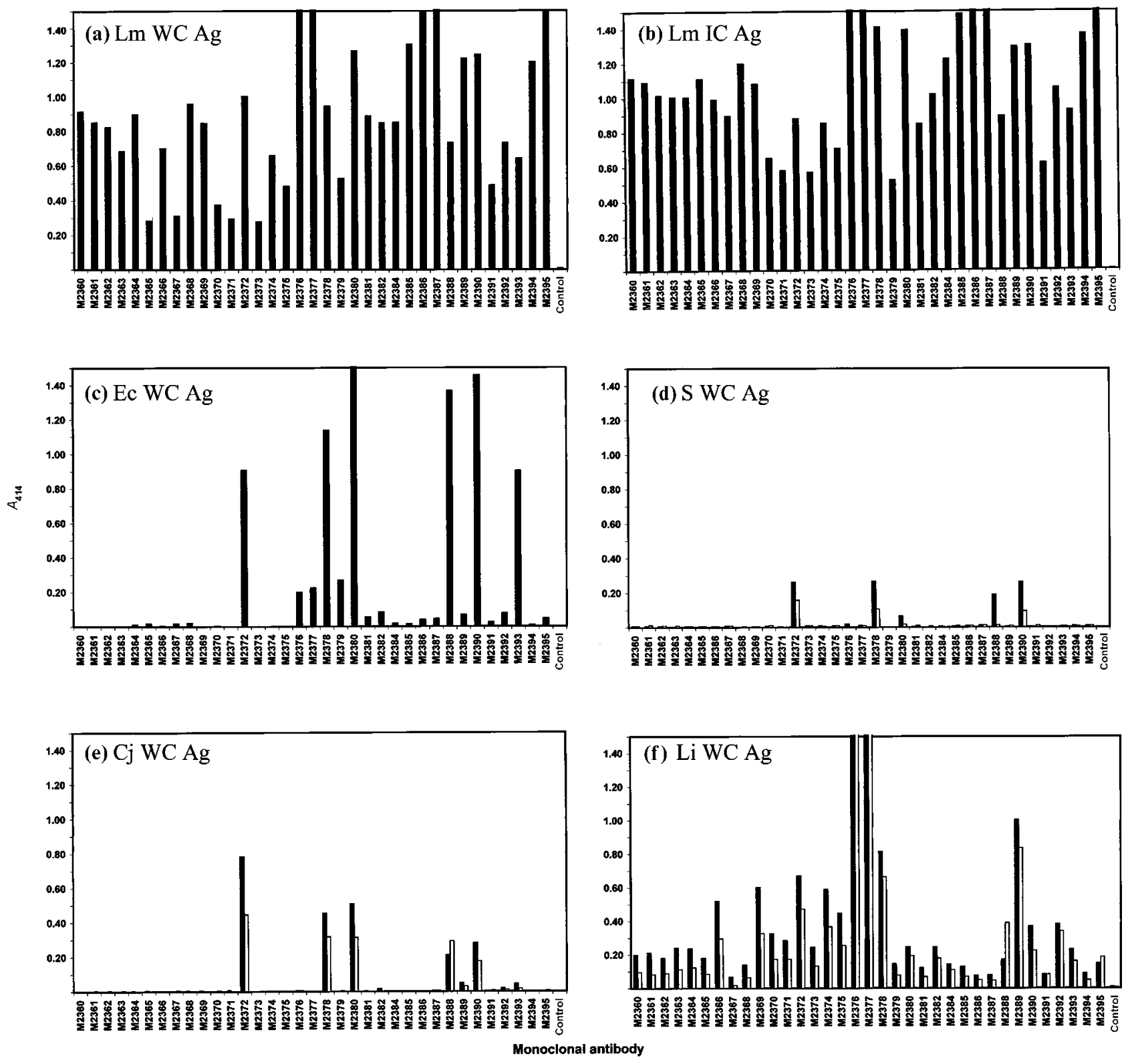

Fig. 1. Analysis of reactivity of mAbs raised against $L$. monocytogenes by ELISA. ELISA plates were coated with WC antigens of $L$. monocytogenes serotype $4 \mathrm{~b}(\mathrm{Lm} \mathrm{WC} \mathrm{Ag)} \mathrm{(a),} \mathrm{IC} \mathrm{antigens} \mathrm{of} \mathrm{L.} \mathrm{monocytogenes} \mathrm{serotype} 4 \mathrm{~b}(\mathrm{Lm} I C \mathrm{Ag})(\mathrm{b})$ and WC antigens of E. coli 0157 : H7 (Ec WC Ag) (c), S. Typhimurium (S WC Ag) (d), C. jejuni (Cj WC Ag) (e) and L. innocua (Li WC Ag) (f) at a dilution of $1: 500$ (solid bars) or 1:1000 (open bars).

\section{Western blot analysis of mAb reactivity}

Analysis of the total cellular antigens of L. monocytogenes using Western blotting (Fig. 2) revealed that 20 out of the $35 \mathrm{mAbs}$ were capable of detecting protein bands of various sizes, while 15 failed to react with any protein band on the blots. M2360, M2361, M2362 and M2389 reacted weakly with a protein band with an apparent molecular mass of $20 \mathrm{kDa} ; \mathrm{M} 2363$ recognized a protein band of $87 \mathrm{kDa}$; M2369 detected a protein of $88 \mathrm{kDa}$ and also a smaller band of $56 \mathrm{kDa}$; M2370, M2371, M2373 and M2374 detected a protein band of approximately $88 \mathrm{kDa}$; M2375 and M2392 reacted with a $77 \mathrm{kDa}$ protein band; M2382 recognized a protein band with an apparent molecular mass of $75 \mathrm{kDa}$; M2384 detected a protein of approximately $62 \mathrm{kDa}$; M2385, M2386, M2387, M2394 and M2395 reacted with a protein band of $35 \mathrm{kDa}$; and M2393 reacted weakly with a protein band of $36 \mathrm{kDa}$. 
Table 1. $\mathrm{mAb}$ reactivity with $E$. coli $0157: \mathrm{H} 7$ (Ec), $S$. Typhimurium DT104 (S), C. jejuni (Cj) and L. innocua (Li) as determined by indirect ELISA

All mAbs listed in the table showed the same reactions with WC and IC antigens of L. monocytogenes serotype $4 \mathrm{~b}$. IC antigens from the other four bacteria were not tested. -, Negative result, $A_{414}<0 \cdot 1 ; \quad+$, positive result, $A_{414}>0 \cdot 3 ; \mathrm{w}+$, weakly positive result, $A_{414}<0 \cdot 3$.

\begin{tabular}{|c|c|c|c|c|c|}
\hline \multirow[t]{2}{*}{$\mathbf{m A b}$} & \multirow[t]{2}{*}{ Isotype } & \multicolumn{4}{|c|}{ Reactivity with ELISA antigens } \\
\hline & & Ec WC & S WC & $\mathrm{Cj}$ WC & Li WC \\
\hline M2360 & G2a & - & - & - & $\mathrm{w}+$ \\
\hline M2361 & G2a & - & - & - & $\mathrm{w}+$ \\
\hline M2362 & $\mathrm{G} 2 \mathrm{a}$ & - & - & - & $\mathrm{w}+$ \\
\hline M2363 & G1 & - & - & - & $\mathrm{w}+$ \\
\hline M2364 & G2a & - & - & - & $\mathrm{w}+$ \\
\hline M2365 & M & - & - & - & $\mathrm{w}+$ \\
\hline M2366 & G2a & - & - & - & + \\
\hline M2367 & $\mathrm{M}$ & - & - & - & $\mathrm{w}+$ \\
\hline M2368 & G1 & - & - & - & $\mathrm{w}+$ \\
\hline M2369 & $\mathrm{G} 2 \mathrm{a}$ & - & - & - & + \\
\hline M2370 & $\mathrm{G} 2 \mathrm{a}$ & - & - & - & + \\
\hline M2371 & $\mathrm{G} 2 \mathrm{a}$ & - & - & - & $\mathrm{w}+$ \\
\hline M2372 & $\mathrm{M}$ & + & $\mathrm{w}+$ & + & + \\
\hline M2373 & G2a & - & - & - & + \\
\hline M2374 & G2a & - & - & - & + \\
\hline M2375 & G2a & - & - & - & + \\
\hline M2376 & $\mathrm{G} 2 \mathrm{a}$ & $\mathrm{w}+$ & - & - & + \\
\hline M2377 & G2a & $\mathrm{w}+$ & - & - & + \\
\hline M2378 & G1 & + & $\mathrm{w}+$ & + & + \\
\hline M2379 & G1 & $\mathrm{w}+$ & - & - & $\mathrm{w}+$ \\
\hline M2380 & M & + & - & + & $\mathrm{w}+$ \\
\hline M2381 & G1 & - & - & - & $\mathrm{w}+$ \\
\hline M2382 & G1 & - & - & - & $\mathrm{w}+$ \\
\hline M2384 & G1 & - & - & - & $\mathrm{w}+$ \\
\hline M2385 & $\mathrm{G} 2 \mathrm{a}$ & - & - & - & $\mathrm{w}+$ \\
\hline M2386 & G1 & - & - & - & - \\
\hline M2387 & G1 & - & - & - & - \\
\hline M2388 & $\mathrm{M}$ & + & $\mathrm{w}+$ & $\mathrm{w}+$ & + \\
\hline M2389 & G1 & - & - & - & + \\
\hline M2390 & M & + & $\mathrm{w}+$ & $\mathrm{w}+$ & + \\
\hline M2391 & G1 & - & - & - & - \\
\hline M2392 & G1 & - & - & - & + \\
\hline M2393 & $\mathrm{M}$ & + & - & - & $\mathrm{w}+$ \\
\hline M2394 & G2a & - & - & - & - \\
\hline M2395 & G1 & - & - & - & $\mathrm{w}+$ \\
\hline
\end{tabular}

\section{Detection of $L$. monocytogenes cell-surface- exposed antigens by mAbs}

Live L. monocytogenes were probed with each of the $35 \mathrm{mAbs}$ followed by immunofluorescent staining. Only M2365 and M2367 recognized antigens present on the cell surface (Fig. 3). Staining by these two mAbs was specific, as no staining was observed with a control mAb M2165 (data not shown). All other mAbs, exemplified in Fig. 3 by M2387, failed to stain live bacteria, indicating that the epitopes recognized by these antibodies are not accessible on the cell surface. Immunofluorescent microscopy also revealed that neither M2365 nor M2367 bound to the cell surface of live E. coli O157:H7, S. Typhimurium or C. jejuni (data not shown). Consistent results were obtained for all of the mAbs with immunogold labelling of L. monocytogenes. Transmission electron microscopy showed immunogold particles on the surface of the bacterium probed with M2365 and M2367 (Fig. 4). Probing with the control mAb M2165 (Fig. 4) and all of the other mAbs directed against L. monocytogenes (data not shown) did not result in the presence of gold particles on the surface of bacterial cells.

\section{Cross-reaction of anti-L. monocytogenes mAbs with other selected bacteria}

All $35 \mathrm{mAbs}$ that were shown to react with the WC and IC antigens of L. monocytogenes (Fig. 1a, b) were tested for reactivity with other food-borne pathogens represented by E. coli $\mathrm{O} 157: \mathrm{H7}$, S. Typhimurium, C. jejuni and the nonpathogenic bacterium $L$. innocua by ELISA (Fig. 1c-f). By using a cut-off $A_{414}$ value of $0 \cdot 1$, which was approximately ten times the value obtained with the control antibody, nine mAbs (M2372, M2376, M2377, M2378, M2379, M2380, M2388, M2390 and M2393) were found to react with E. coli O157:H7 (Fig. 1c), four (M2372, M2378, M2388 and M2390) with S. Typhimurium (Fig. 1d) and five (M2372, M2378, M2380, M2388 and M2390) with C. jejuni (Fig. 1e). All mAbs except for M2366, M2369, M2370, M2372, M2373, M2374, M2375, M2376, M2377, M2378, M2388, M2389, M2390 and M2392 exhibited a weak or no reaction with $L$. innocua, with $A_{414}$ values of $<0 \cdot 3$ (Fig. 1f). The two cell-surface-binding antibodies M2365 and M2367 were tested further by ELISA for interaction with WC antigens derived from L. monocytogenes serotypes 1/2a (LI0527), 1/2b (LI0586) and 3a (LI0508) and Listeria species Listeria grayi (ATCC 19120), Listeria ivanovii (ATCC 19119) and Listeria seeligeri (PHB24) and exhibited no binding to these antigens, with $A_{414}$ values of $\leqslant 0 \cdot 1$.

\section{DISCUSSION}

The aim of this study was to develop mAbs directed against $L$. monocytogenes. A total of $35 \mathrm{mAbs}$ reacting with $L$. monocytogenes was identified by screening the hybridomas produced from three fusions. Binding activities of these mAbs were studied using techniques such as ELISA, Western blotting, epifluorescence microscopy and immunogold electron microscopy. The majority of mAbs identified were IgG1 or IgG2a, with a few being IgM. Of these $35 \mathrm{mAbs}$, only 20 rapidly detected protein bands in Western blots of total cellular proteins, although 5 exhibited weak immunological reactions, indicating that the epitopes defined by these antibodies are linear. The other $15 \mathrm{mAbs}$ exhibiting no reactivity in Western blots probably recognized conformational epitopes, which may have been altered under the denaturing conditions used in SDS-PAGE; alternatively, the 

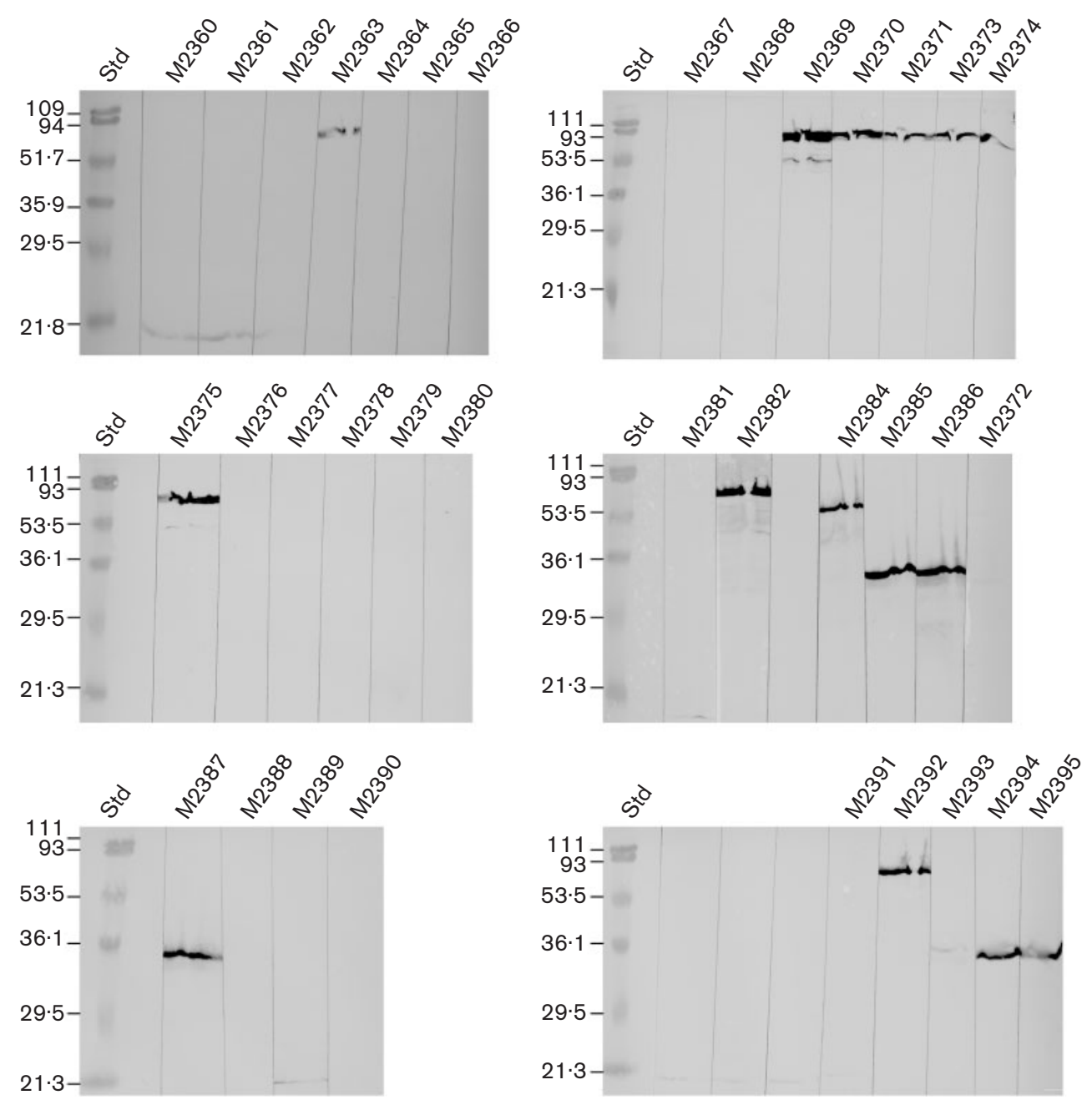

Fig. 2. Western blot analysis of total cell proteins of $L$. monocytogenes serotype $4 \mathrm{~b}$. Total proteins derived from $8 \times 10^{8}$ bacterial cells were probed with each of the $35 \mathrm{mAbs}$ following SDS-PAGE and electroblotting onto a nitrocellulose membrane. Binding was detected by reaction with HRP-conjugated goat anti-mouse $\lg \mathrm{G}(\mathrm{H}+\mathrm{L}$ chain). Protein standards (Std) with their molecular masses in $\mathrm{kDa}$ are shown on the left of the blots. The blank unlabelled lanes in the middle and bottom panels on the right show the results with some of the unreactive mAbs used in the other four panels.

epitopes recognized by them may have been of a nonprotein nature and not transferred efficiently onto the nitrocellulose membranes. This observation is not unusual for anti-Listeria mAbs, as Kathariou et al. (1994) and Torensma et al. (1993) reported that some of their mAbs failed to detect protein bands in Western blots of total cellular proteins. With the exception of M2369, which reacted with a protein of $88 \mathrm{kDa}$ and a smaller protein with an apparent molecular mass of $56 \mathrm{kDa}$, all other mAbs that reacted with $L$. monocytogenes antigens on Western blots detected a single protein band with apparent molecular masses of $20 \mathrm{kDa}$ (four mAbs), $35 \mathrm{kDa}$ (five mAbs), $36 \mathrm{kDa}$ (one $\mathrm{mAb}$ ), $62 \mathrm{kDa}$ (one $\mathrm{mAb}$ ), $75 \mathrm{kDa}$ (one $\mathrm{mAb}$ ), $77 \mathrm{kDa}$ (two mAbs) and $87-88 \mathrm{kDa}$ (six mAbs). In contrast, slightly complicated immunoreaction patterns for mAbs directed against Listeria were demonstrated by Western blotting in several previous studies, detecting two major antigens of 38 and $41 \mathrm{kDa}$ (Loiseau et al., 1995); a protein smear of 40-60 kDa, several vague bands of $\sim 20 \mathrm{kDa}$ and double bands at 90 and $35 \mathrm{kDa}$ (Torensma et al., 1993), multiple bands of 76, 66, 56 and $52 \mathrm{kDa}$ (Bhunia et al., 1991), a protein band of $66 \mathrm{kDa}$ and double bands of 43 and 94-97 kDa (Bhunia \& Johnson, 1992), a $31 \mathrm{kDa}$ flagellin (Kathariou et al., 1994), an $18.5 \mathrm{kDa}$ protein (Siragusa \& Johnson, 1990) and a $104 \mathrm{kDa}$ cell-surface protein (Pandiripally et al., 1999). Thus, the mAbs reported here with reactivity on Western blots appeared to recognize linear epitopes localized on proteins that were different in size from the mAb-reactive proteins described by others (Siragusa \& Johnson, 1990; Bhunia et al., 1991; Bhunia \& Johnson, 1992; Torensma 

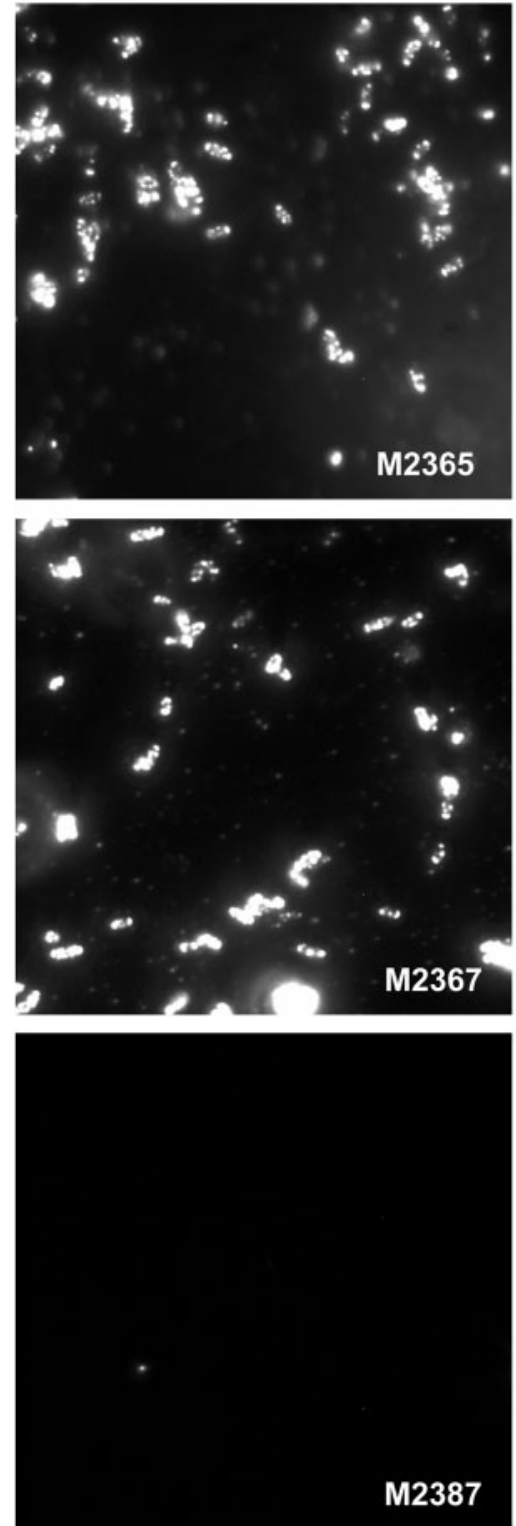
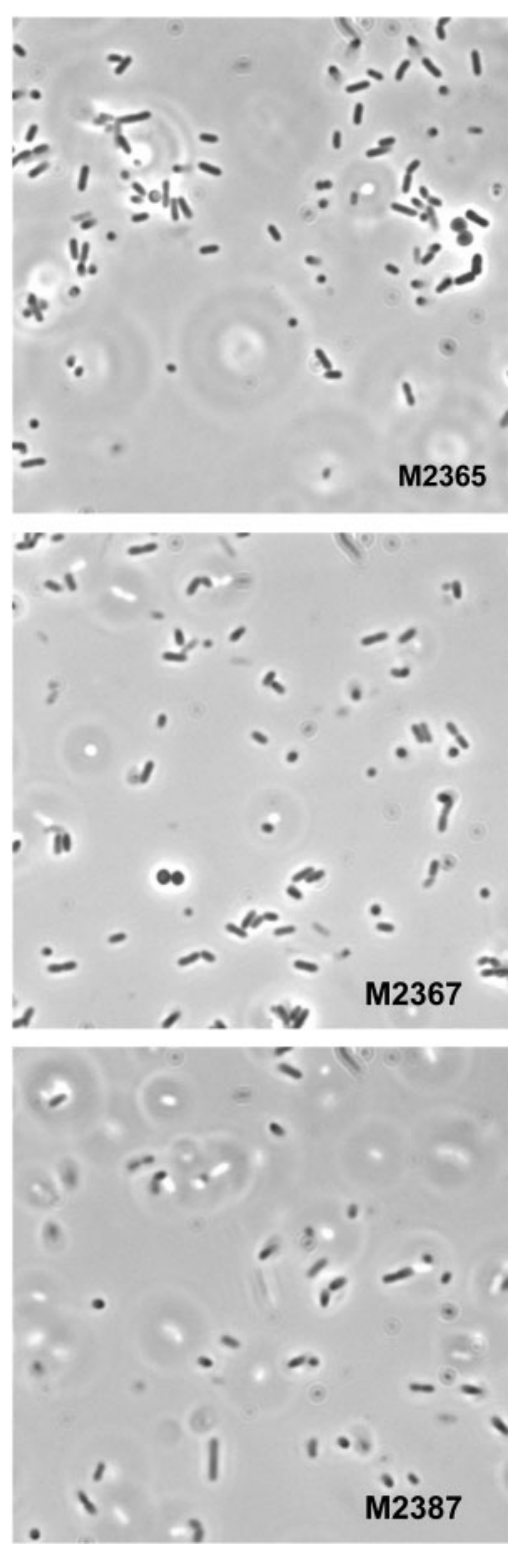

Fig. 3. Immunofluorescent staining of $L$. monocytogenes serotype $4 \mathrm{~b}$. Bacterial cells $\left(2 \times 10^{8}\right)$ were probed with each of the 35 mAbs. Binding was detected by reaction with FITC-conjugated goat anti-mouse $\lg G$ $(\mathrm{H}+\mathrm{L}$ chain). Cells were visualized with a fluorescence microscope. Fluorescent images (left) and phase-contrast images (right) of bacterial cells in the same field are shown for staining with three selected mAbs (M2365, M2367 and M2387). et al., 1993; Kathariou et al., 1994; Loiseau et al., 1995; Pandiripally et al., 1999). Thus, they are likely to be unique immunogenic proteins.

Specific binding to the cell surface with minimal or no crossreaction with other micro-organisms is a desired feature for a $\mathrm{mAb}$ to be useful in the detection of L. monocytogenes. Of the 35 mAbs described here, only M2365 and M2367 recognized cell-surface antigens, as demonstrated by epifluorescence microscopy and immunogold electron microscopy. These two mAbs possibly recognized a conformational epitope, as they did not produce reactivity in Western blot analysis. These two antibodies did not cross-react with $E$. coli O157: H7, C. jejuni and S. Typhimurium, and showed a very weak reaction with total $L$. innocua cellular antigens in ELISA. M2365 and M2367 also failed to recognize the surface antigens of E. coli O157:H7, C. jejuni and S. Typhimurium, as revealed by immunofluorescent staining. In addition, M2365 and M2367 showed no reaction with whole-cell antigens from L. monocytogenes serotypes 1/2a (LI0527), 1/2b (LI0586) and 3a (LI0508) and the Listeria species L. grayi (ATCC 19120), L. ivanovii (ATCC 19119) and L. seeligeri (PHB24) in ELISA. The lack of cross-reaction of M2365 and M2367 with a limited number of L. monocytogenes serotypes and other bacterial species suggests that M2365 and M2367 have potential for use in the immunocapture of live L. monocytogenes for rapid detection in food or other test samples, and for clinical applications such as the detection of the bacterium in infected tissues or cerebrospinal fluid. The use of mAbs as reagents for the development of rapid methods of laboratory diagnosis to detect Listeria from food or clinical samples has been described in other studies (McLauchlin et al., 1988, 1989; McLauchlin \& Taylor, 1989). The present study has added new mAbs to the 

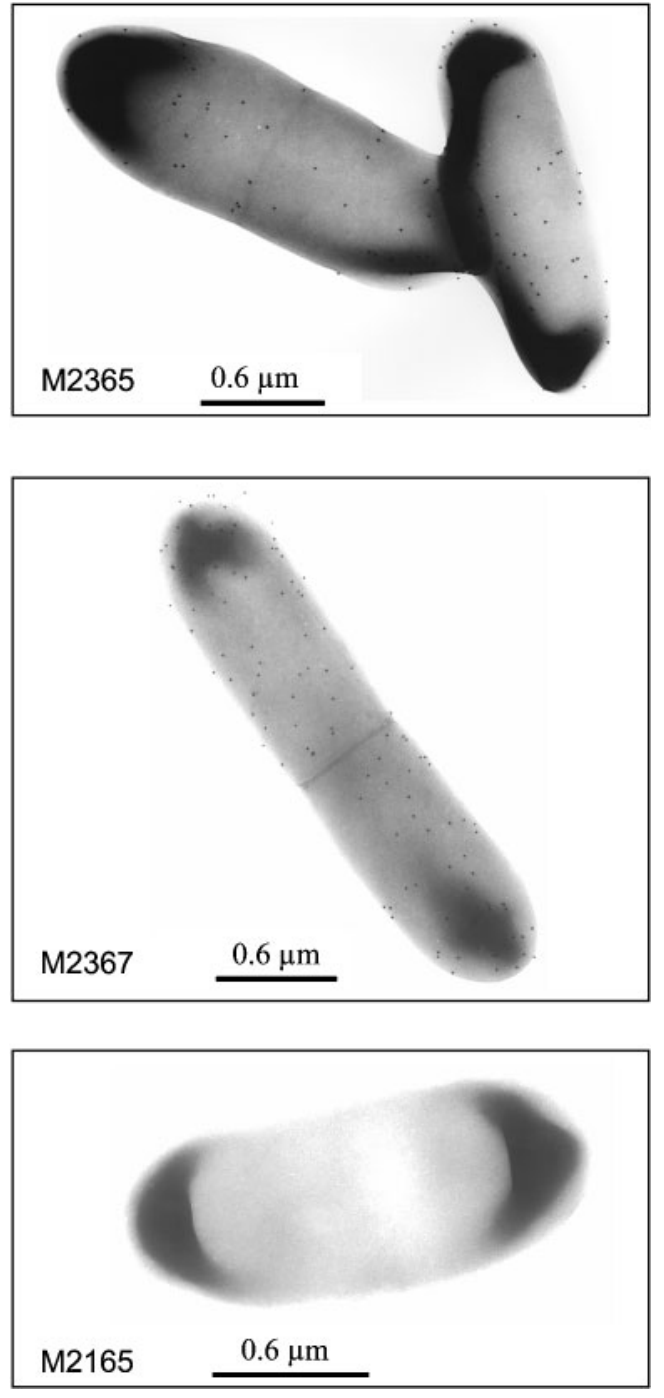

Fig. 4. Detection of $L$. monocytogenes surface antigens by immunogold labelling with mAbs. Bacterial cells $\left(3 \times 10^{8}\right)$ were probed with each of the $35 \mathrm{mAbs}$ followed by detection with $12 \mathrm{~nm}$ gold particle-conjugated goat anti-mouse $\lg G(\mathrm{H}+\mathrm{L}$ chain). Bacterial cells were visualized with a transmission electron microscope at a magnification of $\times 30000$. Images of immunogold labelling with two mAbs (M2365, M2367) and one control mAb (M2165) are shown. Bar, 0.6 $\mu \mathrm{m}$.

diagnostically important antibody list. Those mAbs showing no binding to the surface antigens but demonstrating reactivity with WC lysate and IC antigens in ELISA, as described in this study, may recognize epitopes that are not on the surface but which rapidly become exposed and accessible as a result of the mechanical disruption of intact L. monocytogenes. Of the $35 \mathrm{mAbs}$ directed against $L$. monocytogenes, only a few exhibited a significant crossreaction with E. coli O157: H7, C. jejuni or S. Typhimurium. As expected, there were more mAbs that showed a significant cross-reaction with the antigens of $L$. innocua. Four mAbs (M2372, M2378, M2388 and M2390) appeared to recognize a common conformational epitope among the bacterial species tested, as indicated by ELISA and Western blotting. Four mAbs (M2386, M2391, M2387 and M2394) showed no reaction with E. coli O157:H7, C. jejuni, S. Typhimurium and L. innocua in ELISA, and thus are highly specific for L. monocytogenes. Two mAbs, M2386 and M2394, recognized a linear epitope on proteins with similar molecular masses of $35 \mathrm{kDa}$.

In summary, we have successfully developed a panel of $35 \mathrm{mAbs}$ directed against L. monocytogenes. Some of the mAbs described here may be useful as reagents for the specific detection of the bacterium in food or clinical samples, and as potential probes for serotyping the $4 \mathrm{~b}$ strains and studying their surface-antigen composition.

\section{ACKNOWLEDGEMENTS}

We acknowledge D. Franks for assistance with fluorescent microscopy, B. Phipps-Todd for help with electron microscopy, J. Devenish for assistance in C. jejuni culture and L. Wang for valuable discussion and suggestions about immunofluorescent staining and immunogold labelling procedures. We are also grateful for support from the Small Animal Colony and the Monoclonal Antibody Unit (Canadian Food Inspection Agency, Ottawa Laboratory Fallowfield) for mouse immunization and hybridoma fusion.

\section{REFERENCES}

Ausubel, F. M., Brent, R., Kingston, R. E., Moore, D. D., Seidman, J. G., Smith, J. A. \& Struhl, K. (editors) (2005). Current Protocols in Molecular Biology. New York: Wiley.

Bhunia, A. K. \& Johnson, M. G. (1992). Monoclonal antibody specific for Listeria monocytogenes associated with a 66-kilodalton cell surface antigen. Appl Environ Microbiol 58, 1924-1929.

Bhunia, A. K., Ball, P. H., Fuad, A. T., Kurz, B. W., Emerson, J. W. \& Johnson, M. G. (1991). Development and characterization of a monoclonal antibody specific for Listeria monocytogenes and Listeria innocua. Infect Immun 59, 3176-3184.

Donnelly, C. W. (2001). Listeria monocytogenes: a continuing challenge. Nutr Rev 59, 183-194.

Farber, J. M. \& Speirs, J. I. (1987). Potential use of continuous cell lines to distinguish between pathogenic and nonpathogenic Listeria spp. J Clin Microbiol 25, 1463-1466.

Kathariou, S., Mizumoto, C., Allen, R. D., Fok, A. K. \& Benedict, A. A. (1994). Monoclonal antibodies with a high degree of specificity for Listeria monocytogenes serotype 4b. Appl Environ Microbiol 60, 3548-3552.

Laemmli, U. K. (1970). Cleavage of structural proteins during the assembly of the head of bacteriophage T4. Nature 227, 680-685.

Lin, M., Trottier, E. \& Mallory, M. (2005). Enzyme-linked immunosorbent assay based on a chimeric antigen bearing the antigenic regions of structural proteins $\mathrm{E}^{\mathrm{rns}}$ and $\mathrm{E} 2$ for the serodiagnosis of classical swine fever virus infection. Clin Diagn Lab Immunol 12, 877-881.

Loiseau, O., Cottin, J., Robert, R., Tronchin, G., Mahaza, C. \& Senet, J. M. (1995). Development and characterization of monoclonal antibodies specific for the genus Listeria. FEMS Immunol Med Microbiol 11, 219-230.

Lorber, B. (1997). Listeriosis. Clin Infect Dis 24, 1-9.

McLauchlin, J. \& Taylor, A. G. (1989). The use of monoclonal antibodies in the characterization and purification of cell surface 
antigens of Listeria monocytogenes serogroup 4. Acta Microbiol Hung 36, 459-465.

McLauchlin, J., Black, A., Green, H. T., Nash, J. Q. \& Taylor, A. G. (1988). Monoclonal antibodies show Listeria monocytogenes in necropsy tissue samples. J Clin Pathol 41, 983-988.

McLauchlin, J., Samuel, D. \& Taylor, A. G. (1989). The use of monoclonal antibodies to demonstrate Listeria monocytogenes in post mortem tissue using a direct immunofluorescence technique, and to detect a soluble antigen in CSF supernatants using an ELISA. Acta Microbiol Hung 36, 303-308.

Mead, P. S., Slutsker, L., Dietz, V., McCaig, L. F., Bresee, J. S., Shapiro, C., Griffin, P. M. \& Tauxe, R. V. (1999). Food-related illness and death in the United States. Emerg Infect Dis 5, 607-625.

Norton, D. M. (2002). Polymerase chain reaction-based methods for detection of Listeria monocytogenes: toward real-time screening for food and environmental samples. J AOAC Int 85, 505-515.

Pandiripally, V. K., Westbrook, D. G., Sunki, G. R. \& Bhunia, A. K. (1999). Surface protein p104 is involved in adhesion of Listeria monocytogenes to human intestinal cell line, Caco-2. J Med Microbiol 48, 117-124.

Ralovich, B. (1993). Detection and epidemiological typing of Listeria strains - diagnostic methods for Listeria infections (a review). Acta Microbiol Hung 40, 3-38.
Rocourt, J. \& Bille, J. (1997). Foodborne listeriosis. World Health Stat Q 50, 67-73.

Schlech, W. F., III (1993). An animal model of foodborne Listeria monocytogenes virulence: effect of alterations in local and systemic immunity on invasive infection. Clin Invest Med 16, 219-225.

Schlech, W. F. III (2000). Foodborne listeriosis. Clin Infect Dis 31, 770-775.

Shulman, M., Wilde, C. D. \& Köhler, G. (1978). A better cell line for making hybridomas secreting specific antibodies. Nature 276, 269-270.

Siragusa, G. R. \& Johnson, M. G. (1990). Monoclonal antibody specific for Listeria monocytogenes, Listeria innocua, and Listeria welshimeri. Appl Environ Microbiol 56, 1897-1904.

Torensma, R., Visser, M. J., Aarsman, C. J., Poppelier, M. J., Fluit, A. C. \& Verhoef, J. (1993). Monoclonal antibodies that react with live Listeria spp. Appl Environ Microbiol 59, 2713-2716.

$\mathrm{Yu}, \mathbf{W}$. (2004). The gene products of Listeria monocytogenes induced specifically during rabbit infection. MSc thesis, University of Ottawa, Ottawa, Canada.

Ziegler, H. K. \& Orlin, C. A. (1984). Analysis of Listeria monocytogenes antigens with monoclonal antibodies. Clin Invest Med 7, 239-242.

Zola, H. (1987). Monoclonal Antibodies: a Manual of Techniques. Boca Raton, FL: CRC Press. 